\title{
Evaluasi Simpang Bersinyal (Ber - Apill) Tanjung Barat - Pasar Minggu Berdasarkan MKJI dan Kondisi Lapangan
}

\author{
Evaluation intersection (Ber - Apill) Tanjung Barat - Pasar Minggu \\ Based MKJI and Field Conditions
}

\author{
Hikma Dewita \\ Prodi Teknik Sipil, Universitas Tama Jagakarsa \\ Jl. T.B Simatupang 152 Jakarta \\ Email : hikma_dewita@yahoo.com
}

\begin{abstract}
Signalized Intersection (air-APILL) Tanjung Barat - Pasar Minggu (South Jakarta) is an intersection that had existed before the overpass (fly over) TB. Simatupang was built. Currently the number of vehicles entering the intersection is moving slowly due to the density of traffic flow and as a result of delay (delay). In addition, the presence of lines KRL Jakarta - Depok - Bogar traffic with a frequency high pass makes congestion worse. The purpose of this the research was to evaluate performance of signalized intersection (air-APILL) Tanjung Barat - Pasar Minggu (South Jakarta) adjust arrangements the existing traffic ligtht with arrangement traffic ligtht from the result of the planning (MKJI).

Primary data is obtained by performing a direct survey in the field. Data was processed and analyzed with reference MKJI up performance earned junction. Parameters which will be considered are cycle time, degree of saturation, the number of vehicles queued, long queues, delays and service level junction. It is advisable to avoid the traffic congestion of both traffic flow, the existing cycle time adjusted to the results of the planning cycle time.
\end{abstract}

Keywords: performance of intersection, cycle time, degree of saturation, the number of vehicles queued, long vehicle queues, delays.

\section{PENDAHULUAN}

Simpang bersinyal (ber-APILL) Tanjung Barat - Pasar Minggu (Jakarta Selatan) merupakan persimpangan sebidang yang telah ada sebelum jalan layang (fly over) TB. Simatupang dibangun. Pembangunan jalan layang tersebut direncanakan oleh Dinas Bina Marga dengan tujuan untuk mengatasi permasalahan seperti kemacetan, yang terjadi disekitar persimpangan. Volume arus lalu lintas di persimpangan yang relatif tinggi,dan terdapanya jalur Kereta Listrik JakartaDepok-Bogor memotong persimpangan dengan frekuensi waktu melintas KRL yang tinggi membuat semakin buruknya kondisi lalu di persimpangan tersebut. Dengan adanya sinyal yang menggunakan lampu ini adalah untuk menghindari titik konflik dan pada saat bersamaan akan menambah tundaan pada setiap perlintasan.

Tujuan dari penelitian ini adalah untuk mengevaluasi apakah kinerja simpang bersinyal (ber-APILL) Tanjung Barat Pasar Minggu (Jakarta Selatan) sesuai pengaturan lampu lalu lintas kondisi sebenarnya (eksisting) dengan pengaturan lampu lalu lintas dari hasil perencanaan (MKJI). Dengan mencari waktu siklus dan karakteristik arus lalu lintas dalam kondisi yang ideal (mengabaikan KRL yang melintas) ini diharapkan dapat memberi alternatif pengaturan simpang yang efisien.

\section{Kinerja Simpang}

Menurut MKJI (1997) penentuan tingkat kinerja simpang dengan lampu lalu lintas menggunakan indikator :

- Kapasitas Persimpangan (C)

- Derajat Kejenuhan (DS) 
- Panjang Antrian (NQ)

- Jumlah Kendaraan Terhenti (NS)

- Tundaan (delay)

- Tingkat Pelayanan

\section{Kapasitas Persimpangan (C)}

$$
\begin{aligned}
& \mathrm{C}=\mathrm{S} \times \mathrm{g} / \mathrm{c} \\
& \text { dimana : } \\
& \mathrm{C}=\text { kapasitas (smp/jam(detik) } \\
& \mathrm{S}=\text { Arus jenuh (smp/ jam hijau) } \\
& \mathrm{g}=\text { waktu hijau (detik) } \\
& \mathrm{c}=\text { waktu siklus (detik) }
\end{aligned}
$$

\section{a. Arus Jenuh (S)}

$$
\mathrm{S}=\mathrm{S}_{\mathrm{0}} \times \mathrm{F}_{\mathrm{CS}} \times \mathrm{F}_{\mathrm{SF}} \times \mathrm{F}_{\mathrm{P}} \times \mathrm{F}_{\mathrm{G}} \times \mathrm{F}_{\mathrm{RT}} \times \mathrm{F}_{\mathrm{LI}}
$$

dimana :

So $=$ arus jenuh dasar (smp/jam)

$\mathrm{F}_{\mathrm{CS}}=$ faktor koreksi ukuran kota

$F_{\mathrm{SF}}=$ faktor koreksi hambatan samping

$\mathrm{F}_{\mathrm{P}}=$ faktor koreksi parkir

$\mathrm{F}_{\mathrm{G}}=$ faktor koreksi kelandaian

$F_{\mathrm{RT}}=$ faktor koreksi belok kanan

$F_{\mathrm{LT}}=$ faktor koreksi belok kiri

\section{b. Arus Jenuh Dasar (So)}

$$
\text { So }=600 \times \mathrm{We}
$$

dimana :

So $=$ arus jenuh dasar $(\mathrm{smp} / \mathrm{jam})$

$\mathrm{We}=$ lebar efektif $(\mathrm{m})$

\section{c. Waktu Siklus (c)}

$$
c=\frac{(1,5 \times L M+5)}{\left(1-\Sigma F R_{\text {crit }}\right)}
$$

dimana :

LTI $=$ total waktu hilang per siklus (detik)

$\mathrm{FR}=$ Arus dibagi dengan arus jenuh $(\mathrm{Q} / \mathrm{S})$
Frcrit = Nilai FR tertinggi dari semua pendekat yang berangkat pada suatu fase sinyal

$\sum($ Frcrit $)=$ Rasio arus simpang $=$ jumlah Frcrit dari semua fase pada siklus tersebut

\section{d. Waktu Hijau (g)}

$$
\mathrm{g}_{1}=(\mathrm{c}-\mathrm{LTI}) \mathrm{x} \text { FRcrit } / \sum \text { (FRcrit) }
$$

dimana :

$$
\begin{array}{ll}
\mathrm{g}_{1} & =\text { waktu hijau dalam fase-i } \\
& \\
& \text { (detik) } \\
\mathrm{c} & =\text { waktu siklus sinyal (detik) } \\
\text { LTI } & =\text { jumlah waktu hilang }
\end{array}
$$

FRcrit $=$ Nilai FR tertinggi dari semua pendekat yang berangkat pada suatu fase

$\sum($ FRcrit $)=$ rasio arus simpang

\section{Derajat Kejenuhan (DS)}

$$
\mathrm{DS}=\frac{\mathrm{Q}}{\mathrm{C}}=\frac{\mathrm{Qx} \mathrm{c}}{\mathrm{S}_{\mathrm{xg}}}
$$

dimana :

$$
\begin{aligned}
& \mathrm{DS}=\text { Derajat kejenuhan } \\
& \mathrm{Q}=\operatorname{arus} \text { lalu lintas }(\mathrm{smp} / \mathrm{jam}) \\
& \mathrm{C}=\operatorname{kapasita}(\mathrm{smp} / \mathrm{jam})
\end{aligned}
$$

\section{Panjang Antrian (NQ)}

$$
\mathrm{NQ}=\mathrm{NQ}_{1}+\mathrm{NQ}_{2}
$$

dimana :

$$
\begin{aligned}
\mathrm{NQ} \mathrm{=} & \text { panjang antrian (smp) } \\
\mathrm{NQ}_{1}= & \text { Jumlah kendaraan (smp) yang } \\
& \text { tersisa dari fase hijau } \\
& \text { sebelumnya. } \\
\mathrm{NQ}_{2}= & \text { Jumlah kendaraan (smp) yang } \\
& \text { datang selama fase merah }
\end{aligned}
$$

a. $\quad \mathrm{NQ}_{1}=$ Jumlah kendaraan (smp) yang tersisa dari fase hijau sebelumnya.

$$
\begin{aligned}
& \text { Untuk DS > 0,5 } \\
& \mathrm{NQ}_{1}=0,25 \times \mathrm{C} \times\left\{(\mathrm{DS}-1)+\sqrt{(\mathrm{DS}-1)^{2}+\frac{8 \times(\mathrm{DS}-0,5)}{\mathrm{C}}}\right\}
\end{aligned}
$$

Untuk DS $\leq 0,5$, maka $\mathrm{NQ}_{1}=0$ 
dimana :

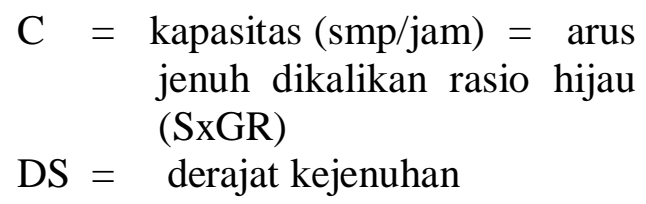

b. $\quad \mathrm{NQ}_{2}=$ Jumlah kendaraan (smp) yang datang selama fase merah

$$
\mathrm{NQ}_{2}=\mathrm{cx} \frac{1-\mathrm{GR}}{1-\mathrm{GR} \times \mathrm{DS}} \times \frac{\mathrm{Q}}{3600}
$$

dimana :

$$
\begin{aligned}
\mathrm{GR}= & \text { rasio hijau }=\mathrm{g} / \mathrm{c} \\
\mathrm{DS}= & \text { derajat kejenuhan } \\
\mathrm{c}= & \text { waktu siklus (det) } \\
\mathrm{Q}_{\text {masul: }}= & \text { arus lalu lintas pada tempat } \\
& \text { masuk diluar LTOR }
\end{aligned}
$$

\section{Jumlah Kendaraan Terhenti (NS)}

$$
\begin{aligned}
& \mathrm{NS}=0,9 \times \frac{\mathrm{NQ}}{\mathrm{Q} \times \mathrm{c}} \times 3600 \\
& \text { dimana : } \\
& \mathrm{NS}=\text { jumlah kendaraan terhenti atau } \\
& \quad \text { angka henti (smp) } \\
& \mathrm{NQ}=\text { panjang antrian (smp) } \\
& \mathrm{Q}=\text { arus lalu lintas (smp/jam) } \\
& \mathrm{c} \quad=\text { waktu siklus (detik) }
\end{aligned}
$$

\section{Tundaan (Delay)}

$$
\mathrm{D}=\mathrm{DT}+\mathrm{DG}
$$

dimana :

$\mathrm{D}=$ tundaan rata-rata pendekat (det/smp)

DT $=$ tundaan lalu lintas rata-rata (det/smp)

$\mathrm{DG}=$ tundaan geometrik rata-rata $(\operatorname{det} / \mathrm{smp})$

a. Tundaan Lalu lintas (DT)

$$
\mathrm{DT}=\mathrm{c} \times \frac{0,5 \times(1-\mathrm{GR})^{2}}{(1-\mathrm{GR} \times \mathrm{DS})}+\frac{\mathrm{NQ}_{1} \times 3600}{\mathrm{C}}
$$

dimana :

$$
\begin{aligned}
\mathrm{DT} & =\text { Tundaan lalu lintas } \\
& (\text { detik/smp }) \\
\mathrm{c} & =\text { waktu siklus }(\mathrm{det}) \\
\mathrm{GR}= & \text { rasio hijau }(\mathrm{g} / \mathrm{c}) \\
\mathrm{DS}= & \text { derajat kejenuhan } \\
\mathrm{NQ}_{1} & =\text { Jumlah kendaraan }(\mathrm{smp})
\end{aligned}
$$

yang tersisa dari fase hijau sebelumnya

b. Tundaan Geometrik (DG)

$$
\left.D G=\left(1-P_{S V}\right) \times P_{t} \times 6+\left(P_{S V} \times 4\right)\right)
$$

dimana :

$\mathrm{DG}=$ tundaan geometri rata-rata pendekat (det/smp)

$P_{\text {SV }}=$ rasio kendaraan terhenti pada suatu pendekat

$P_{\mathrm{t}}=$ rasio kendaraan membelok pada suatu pendekat

\section{Tingkat Pelayanan}

Tabel 1. Tingkat Pelayanan Simpang

\begin{tabular}{|c|c|}
\hline Tundaan (detik/smp) & Tingkat Pelayan \\
\hline$\leq 5.00$ & $\mathrm{~A}$ \\
\hline$>5.00 \geq 15.00$ & $\mathrm{~B}$ \\
\hline$>15.00 \geq 25.00$ & $\mathrm{C}$ \\
\hline$>25.00 \geq 40.00$ & $\mathrm{D}$ \\
\hline$>40.00 \geq 60.00$ & $\mathrm{E}$ \\
\hline$>60.00$ & $\mathrm{~F}$ \\
\hline
\end{tabular}

Sumber : Wikrama,2010

\section{Karakteristik Sinyal Lalu lintas}

Penggunakan sinyal dengan lampu tiga warna (hijau, kuning, merah) ditetapkan untuk memisahkan lintasan dari gerakan-gerakan lalu lintas yang saling bertantangan dalam dimensi waktu. (MKJI,1997)

\section{Waktu Antar Hijau dan Waktu Kuning}

Penentuan waktu antar hijau (intergreen) diambil dari perbedaan antar akhir waktu hijau suatu fase dengan awal waktu hijau pada fase berikutnya. Lamanya waktu kuning ini umumnya diambil tiga detik.

\section{Waktu Hijau Efektif}

Waktu Hijau Efektif = Tampilan Waktu Hijau - Kehilangan Awal + Tambahan Akhir 
Waktu hilang total $(\mathrm{LTI})=$ merah semua total + waktu kuning (det/siklus)

$$
\text { Merah semua }=\left[\frac{\left(\mathrm{L}_{\mathrm{EV}}+\mathrm{I}_{\mathrm{EV}}\right)}{\mathrm{V}_{\mathrm{EV}}}-\frac{\mathrm{L}_{\mathrm{AV}}}{\mathrm{v}_{\mathrm{AV}}}\right]
$$

dimana :

$\mathrm{L}_{\mathrm{EV}}=$ jarak dari garis henti ke titik konflik masing-masing untuk kendaraan yang berangkat $(\mathrm{m})$

$\mathrm{L}_{\mathrm{AV}}=$ jarak dari garis henti ke titik konflik masing-masing untuk kendaraan yang datang $(\mathrm{m})$

$\mathrm{I}_{\mathrm{EV}}=$ panjang kendaraan yang berangkat (m)

$\mathrm{V}_{\mathrm{EV}}=$ kecepatan masing-masing kendaraan yang berangkat $(\mathrm{m} / \mathrm{det})$

$\mathrm{V}_{\mathrm{AV}}=$ kecepatan masing-masing kendaraan yang datang $(\mathrm{m} / \mathrm{det})$

$\mathrm{LTI}=\sum$ (Merah semuatKuning $)_{\mathrm{i}}=\sum \mathrm{IG}_{\mathrm{i}}$ dimana :

$\sum \mathrm{IG}_{\mathrm{i}}=$ total waktu antar hijau $=$ total intergreen (detik)

\section{METODOLOGI}

\section{Bagan Alir Penelitian}

Bagan alir kegiatan penelitian ini disajikan pada Gambar berikut

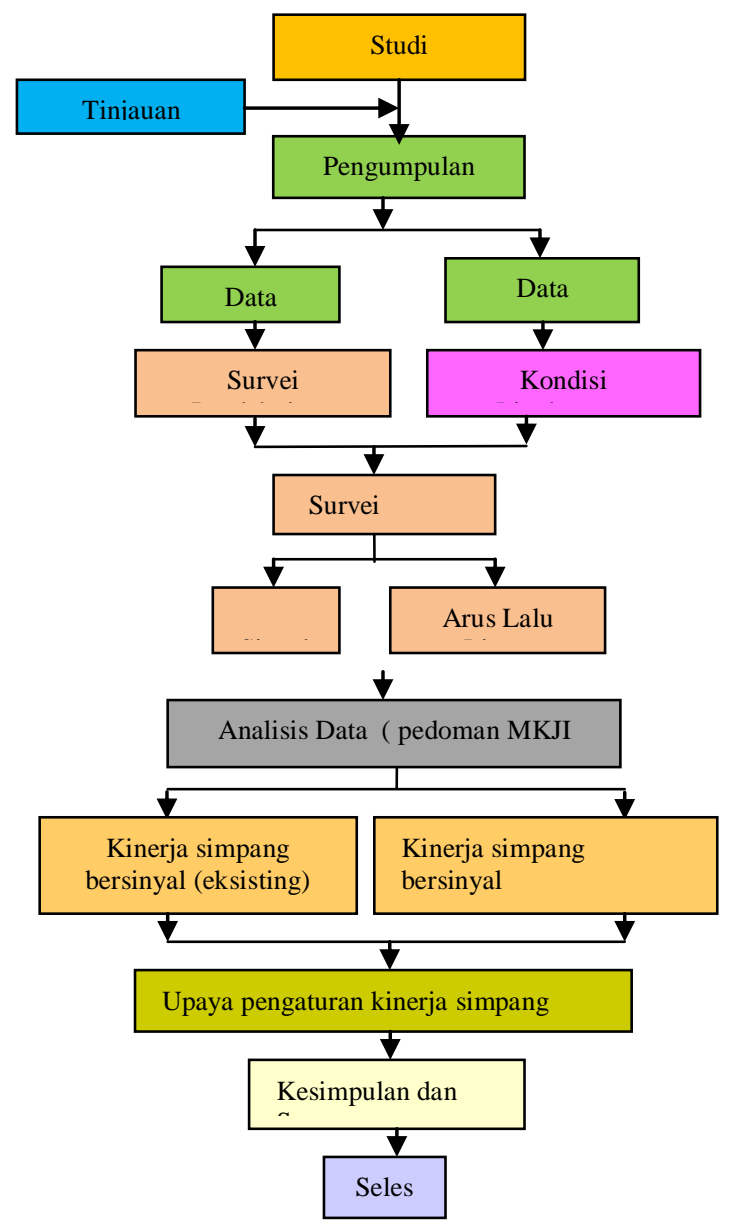

2. Gambaran Umum Kondisi Lokasi Penelitian

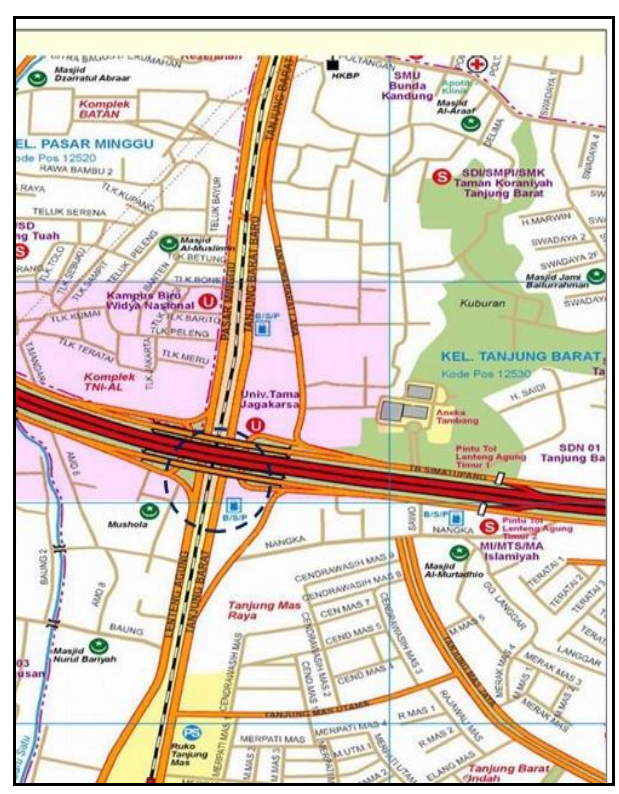

Gambar.1 Denah lokasi simpang 
Pengumpulan data primer diawali dengan survei pendahuluan. Survei pendahuluan ini dengan melakukan pengukuran seperlunya berdasarkan penaksiran di lapangan, sehingga dapat dibuat sketsa pola geometrik. Sketsa pola geometrik tersebut untuk memberikan gambaran bentuk, dimensi dan kondisi lingkungan dari simpang yang diteliti. Dari survei ini, diketahui pola geometri simpang seperti pada Gambar.II

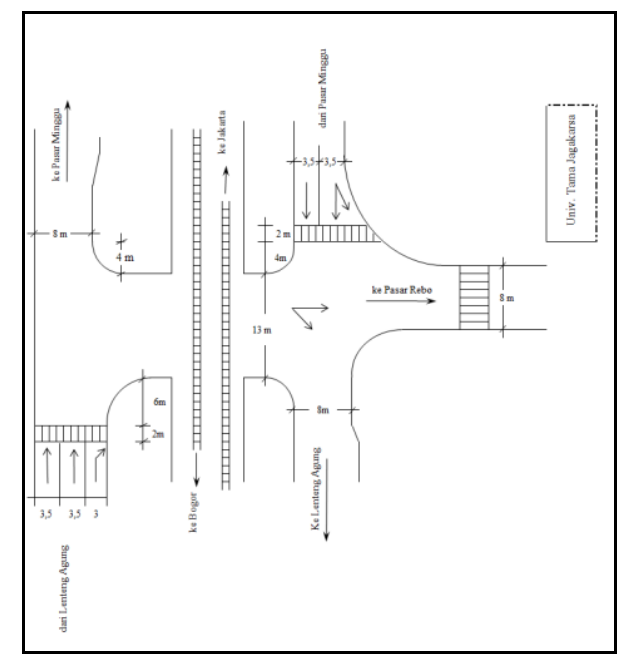

Gambar 2. Geometrik simpang

Selain geometrik simpang, dengan survei pendahuluan dapat ditetapkan juga jumlah fase gerakan pada saat hijau adalah 2 (dua) fase , antara lain (Gambar III) :

- Fase 1: arus lalu lintas dari arah Pasar Minggu menuju Lenteng Agung bergerak, dan arus dari arah Lenteng Agung menuju Pasar Rebo dalam keadaan diam (tidak bergerak).

- Fase 2: arus lalu lintas dari arah Lenteng Agung menuju Pasar Rebo bergerak, dan arus dari arah Pasar Minggu menuju Lenteng dalam keadaan diam (tidak bergerak).
Fase 1

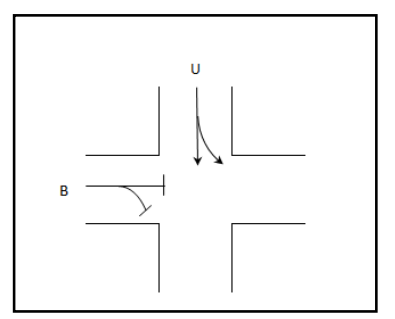

Gambar 3. Fase simpang

\section{HASIL}

\section{Hasil Survei Arus Lalu Lintas}

Pengumpulan data arus lalu lintas, dilakukan dengan mencacah arus lalu lintas per kaki simpang. Pencacahan arus lalu lintas diklasifikasikan berdasarkan jenis kendaraan dan arah arus. Pengklasifikasian kendaraan menjadi kendaraan berat (Heavy Vehicle, HV), kendaraan ringan (Light Vehicle, LV) dan sepeda motor (Motorcycle, MC). Pencacahan arus lalu lintas dikelompokkan per periode waktu setiap 15 (lima belas) menit. Hal ini dimaksud agar fluktuasi arus lalu lintas sepanjang periode survei dapat dievaluasi. Arah arus lalu lintas yang ditinjau antara lain :

1. Lenteng Agung menuju Pasar Minggu (lurus)

2. Lenteng Agung menuju Pasar Rebo (lurus dan belok kanan)

3. Pasar Minggu menuju Lenteng Agung (lurus dan belok kiri). 
Tabel 2. Total kendaraan pada jam puncak pagi

\begin{tabular}{|c|c|c|c|c|c|c|c|c|}
\hline \multirow{3}{*}{ No } & \multirow{3}{*}{ Pukul } & \multicolumn{6}{|c|}{ Jenis Kendaraan } & \multirow{3}{*}{\begin{tabular}{|c|} 
Total \\
Kendjjam \\
\end{tabular}} \\
\hline & & \multicolumn{2}{|c|}{\begin{tabular}{|l|} 
Kendaraan Ringan (LV) \\
\end{tabular}} & \multicolumn{2}{|c|}{ Kendaraan Berat (HV) } & \multicolumn{2}{|c|}{ Sepeda Motor (MC) } & \\
\hline & & Kend/15' & Kendjam & Kend $15^{\prime}$ & Kendjam & Kend $/ 15^{\prime}$ & \begin{tabular}{|l|} 
Kend ${ }^{\prime} \mathrm{am}$ \\
\end{tabular} & \\
\hline \multirow{2}{*}{\multicolumn{9}{|c|}{ Arus : Lenteng Agung - Pasar Minggu }} \\
\hline \multicolumn{6}{|c|}{ Arah : lurus } & & & \\
\hline 1 & $06.45-07.00$ & 160 & & 5 & & 2721 & & \\
\hline 2 & $07.00-07.15$ & 142 & & 4 & & 3045 & & \\
\hline 3 & $07.15-07.30$ & 65 & & 3 & & 2720 & & \\
\hline 4 & $07.30-07.45$ & 114 & 481 & 0 & 12 & 2509 & 10995 & 11488 \\
\hline \multicolumn{9}{|c|}{$\begin{array}{l}\text { Arus : Lenteng Agung - Pasar Rebo } \\
\text { Arah : lurvs }\end{array}$} \\
\hline \begin{tabular}{|l}
1 \\
\end{tabular} & $07.00-07.15$ & 157 & & 2 & & 553 & & \\
\hline 2 & $07.15-07.30$ & 103 & & 11 & & 404 & & \\
\hline 3 & $07.30-07.45$ & 114 & & 3 & & 513 & & \\
\hline & $07.45-08.00$ & 143 & 517 & 9 & 25 & 544 & 2014 & 2556 \\
\hline \multicolumn{9}{|c|}{\begin{tabular}{|l|} 
Arah : Belok kanan \\
\end{tabular}} \\
\hline \begin{tabular}{|l|}
1 \\
$r$
\end{tabular} & $07.30-07.45$ & 22 & & 1 & & 147 & & \\
\hline 2 & $07.45-08.00$ & 15 & & 1 & & 179 & & \\
\hline 3 & $08.00-08.15$ & 9 & & 0 & & 171 & & \\
\hline 41 & $08.15-08.30$ & 22 & 68 & 2 & 4 & 235 & 732 & 804 \\
\hline \multicolumn{9}{|c|}{$\begin{array}{l}\text { Arus : Pasar Minggu - Lenteng Agung } \\
\text { Arah : lurvs }\end{array}$} \\
\hline 1 & $08.30-08.45$ & 68 & & 2 & & 1447 & & \\
\hline 2 & $08.45-09.00$ & 101 & & 2 & & 1218 & & \\
\hline 3 & 09.00-09.15 & 111 & & 3 & & 1346 & & \\
\hline & 09.15-09.30 & 110 & 390 & 3 & 10 & 1002 & 5013 & 5413 \\
\hline \multicolumn{9}{|c|}{ Arah : Belok kiri } \\
\hline 1 & $07.00-07.15$ & 7 & & 0 & & 11 & & \\
\hline 2 & $07.15-07.30$ & 13 & & 1 & & 7 & & \\
\hline 3 & $07.30-07.45$ & 6 & & 0 & & 6 & & \\
\hline 4 & $07.45-08.00$ & 11 & 37 & 1 & 2 & 16 & 40 & 79 \\
\hline
\end{tabular}

Tabel 3. Total kendaraan pada jam puncak sore

\begin{tabular}{|c|c|c|c|c|c|c|c|c|}
\hline \multirow{3}{*}{ No } & \multirow{3}{*}{ Pukul } & \multicolumn{6}{|c|}{ Jenis Kendaraan } & \multirow{3}{*}{$\begin{array}{c}\text { Total } \\
\text { Kend jam }\end{array}$} \\
\hline & & \multicolumn{2}{|c|}{\begin{tabular}{|l|} 
Kendaraan Ringan (LV) \\
\end{tabular}} & \multicolumn{2}{|c|}{ Kendaraan Berat (HV) } & \multicolumn{2}{|c|}{ Sepeda Motor (MC) } & \\
\hline & & 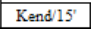 & Kendjjam & Kend $15^{\prime}$ & Kendjam & Kend $15^{\prime}$ & Kendjam & \\
\hline \multirow{2}{*}{\multicolumn{9}{|c|}{ Arus : Lenteng Agung - Pasar Minggu }} \\
\hline \multicolumn{7}{|c|}{ Arah : lurus } & & \\
\hline \begin{tabular}{|l|l|l|l}
1 \\
\end{tabular} & $15.30-15.45$ & 130 & & 7 & & 431 & & \\
\hline 2 & $15.45-16.00$ & 122 & & 7 & & 480 & & \\
\hline 3 & $16.00-16.15$ & 159 & & 7 & & 524 & & \\
\hline 4 & $16.15-16.30$ & 130 & 541 & 6 & 27 & 414 & 1849 & 2417 \\
\hline \multicolumn{9}{|c|}{ Arus : Lenteng Agung - Pasar Rebo } \\
\hline \begin{tabular}{|l|l|}
1 \\
\end{tabular} & 18.00-18.15 & 260 & & 10 & & 302 & & \\
\hline 2 & $18.15-18.30$ & 256 & & 15 & & 254 & & \\
\hline 3 & $18.30-18.45$ & 199 & & 26 & & 303 & & \\
\hline \begin{tabular}{|l|}
4 \\
\end{tabular} & $18.45-19.00$ & 623 & 1338 & 19 & 70 & 330 & 1189 & 2597 \\
\hline \multicolumn{9}{|c|}{ Arah : Belok kanan } \\
\hline \begin{tabular}{|l|l|l|l|l|l}
1 \\
\end{tabular} & 18.00-18.15 & 54 & & 0 & & 363 & & \\
\hline 2 & $18.15-18.30$ & 10 & & 0 & & 305 & & \\
\hline 3 & $18.30-18.45$ & 26 & & 15 & & 431 & & \\
\hline & $18.45-19.00$ & 36 & 126 & 0 & 15 & 403 & 1502 & 1643 \\
\hline \multicolumn{9}{|c|}{$\begin{array}{l}\text { Arus : Pasar Minggu - Lenteng Agung } \\
\text { Arah : lurvs }\end{array}$} \\
\hline 1 & $17.45-18.00$ & 204 & & 19 & & 2771 & & \\
\hline 2 & $18.00-18.15$ & 163 & & 22 & & 2740 & & \\
\hline 3 & $18.15-18.30$ & 125 & & 35 & & 2336 & & \\
\hline 4 & $18.30-18.45$ & 234 & 726 & 10 & 86 & 2517 & 10364 & 11176 \\
\hline \multicolumn{9}{|c|}{ Arah : Belok kiri } \\
\hline \begin{tabular}{|l|l|l|l|l|l|l}
1 \\
\end{tabular} & $14.00-14.15$ & 12 & & 1 & & 26 & & \\
\hline 2 & $14.15-14.30$ & 16 & & 3 & & 28 & & \\
\hline 3 & $14.30-14.45$ & 10 & & 1 & & 19 & & \\
\hline 4 & $14.45-15.00$ & 11 & 49 & 3 & 8 & 21 & 94 & 151 \\
\hline
\end{tabular}

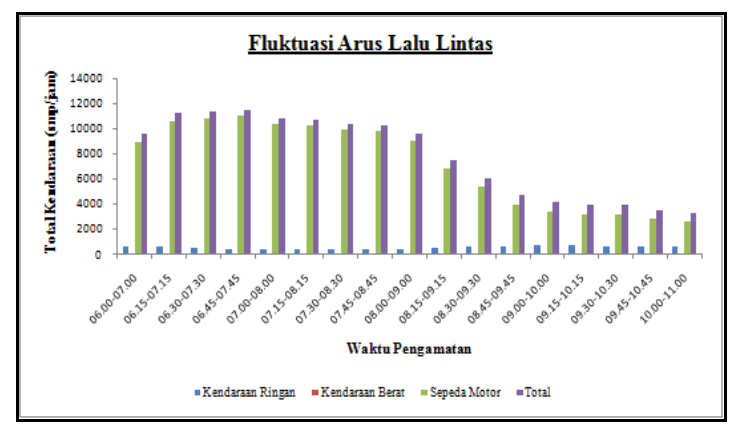

Gambar 4. Grafik fluktuasi arus 1alu lintas Lurus arah Lenteng Agung- Pasar Minggu

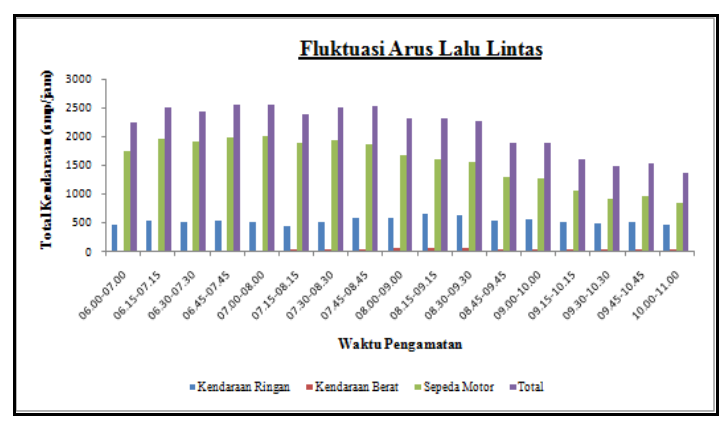

Gambar 5. Grafik fluktuasi arus lalu lalu lintas lurus arah Lenteng AgungPasar Rebo (pagi)

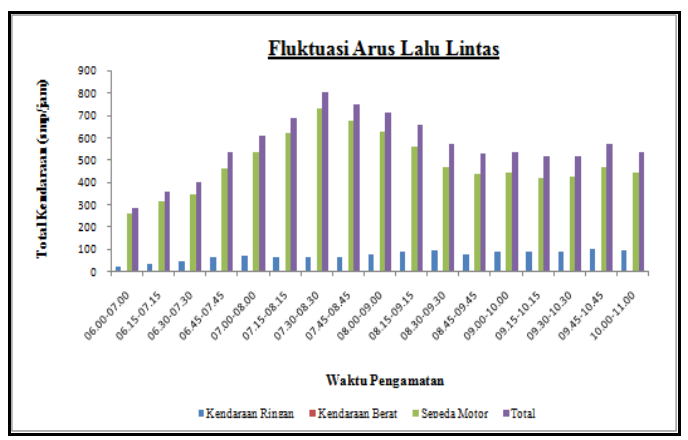

Gambar 6. Grafik fluktuasi arus lalu lintas belok kanan arah Lenteng Agung - Pasar Rebo (pagi) 


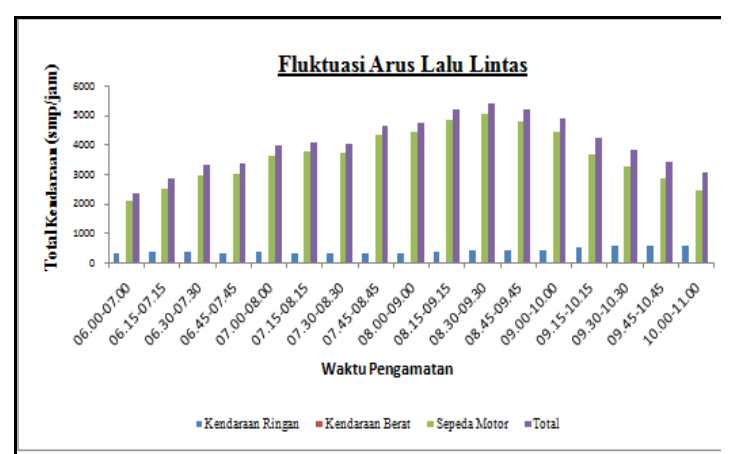

Gambar 7. Grafik fluktuasi arus lalu lintas lurus arah Pasar Minggu - Ltg Agung (pagi)

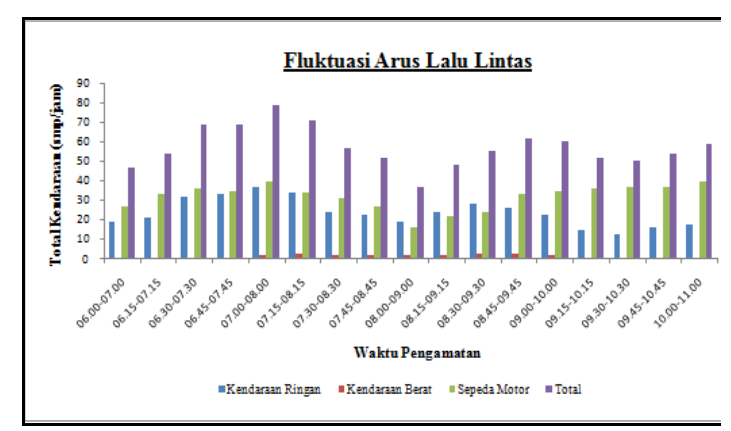

Gambar 8. Grafik fluktuasi arus lalu lintas belok kiri arah Psr Minggu - Lt Agung (pagi)

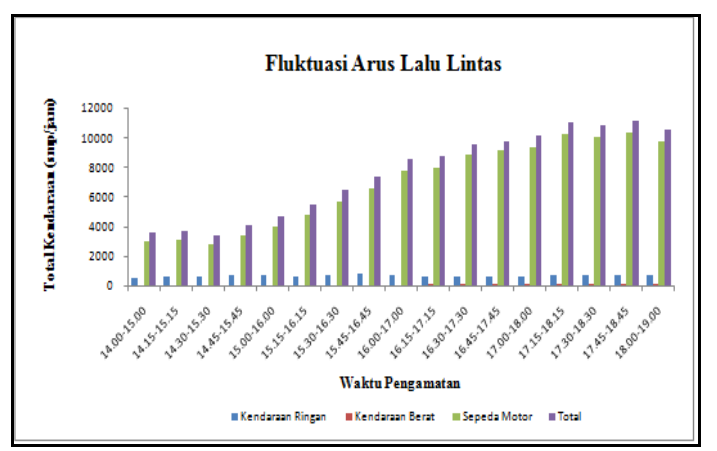

Gambar 9. Grafik fluktuasi arus lalu lintas lurus arah Ps. Mimggu - Lt.

Agung (sore)

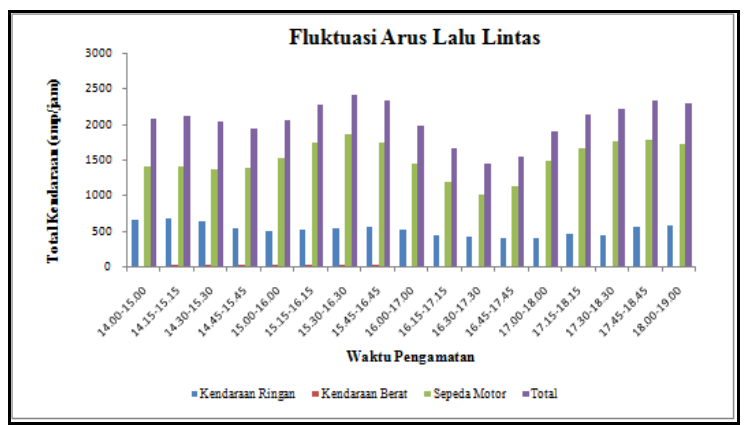

Gambar 10. Grafik fluktuasi arus lalu lintas lurus arah Lenteng Agung - Pasar Minggu (sore)

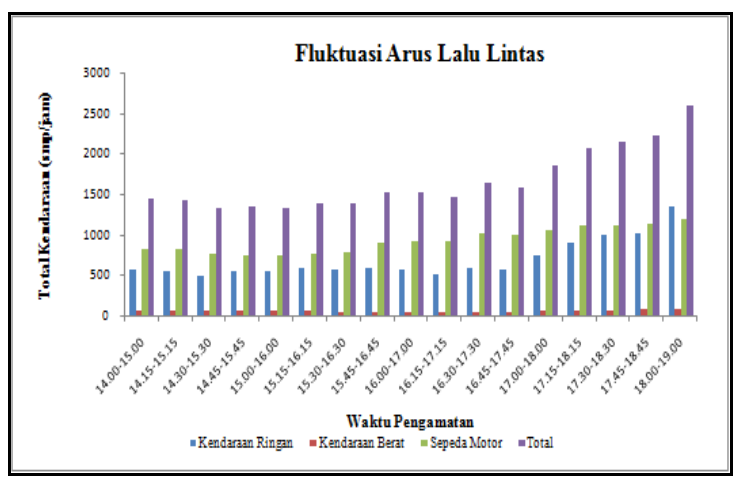

Gambar 11.Grafik fluktuasi arus lalu lintas lurus arah Lenteng Agung - Pasar Rebo (sore)

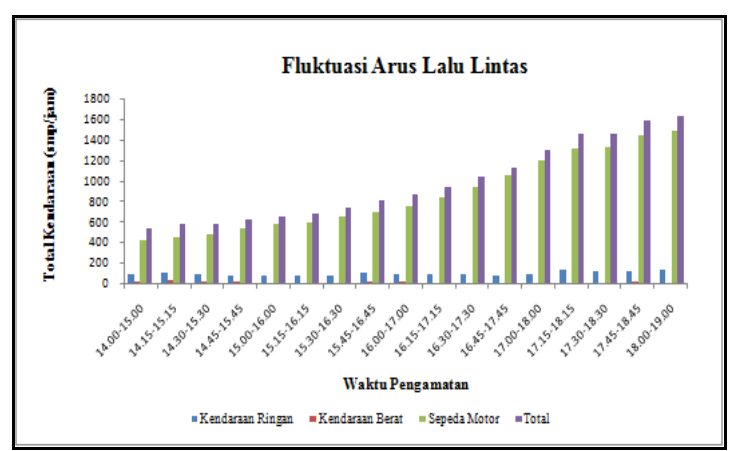

Gambar 12. Grafik fluktuasi arus lalu lintasbel kanan arah Lenteng Agung - Pasar Rebo (sore) 


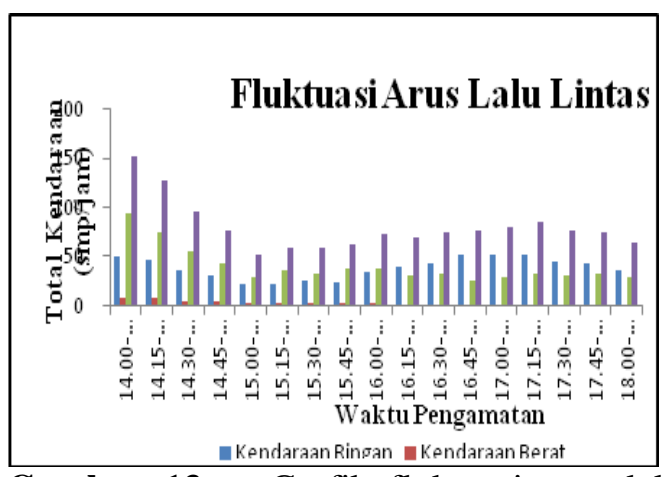

Gambar 13. Grafik fluktuasi arus lalu lintas belok kanan arah Ps. Minggu-Lt. Agung (sore)

\section{Hasil survei waktu persinyalan}

Pengamatan pagi dilakukan pada pukul 08.00-09.00 dan jam sibuk sore pukul 16.00-17.00. Untuk pagi, waktu merah arah Pasar Minggu menuju Lenteng Agung dimulai pukul 08.02:00 dan arah Lenteng Agung menuju Pasar Rebo waktu merah dimulai pukul 08:00:55. Sedangkan untuk sore, waktu merah arah Pasar Minggu menuju Lenteng Agung dimulai pukul 16.00:00 dan arah Lenteng Agung menuju Pasar Rebo waktu merah dimulai pukul 16:02:56. Dari hasil reduksi data tersebut pada Tabel 4 dan Tabel 5

Tabel 4. Waktu persinyalan pagi (sibuk pagi)

\begin{tabular}{|l|l|c|c|c|}
\hline \multirow{2}{*}{ No } & \multicolumn{1}{|c|}{ Arah Arus } & \multicolumn{3}{c|}{ Lama Waktu } \\
\cline { 3 - 5 } & \multicolumn{1}{|c|}{ Persinyalan (detik) } \\
\hline 1 & $\begin{array}{l}\text { Par Minggu - Lng } \\
\text { Agung }\end{array}$ & 110 & 2 & 110 \\
\hline 2 & $\begin{array}{l}\text { Ltg Agung - } \\
\text { Pasar Rebo }\end{array}$ & 80 & 2 & 80 \\
\hline
\end{tabular}

\begin{tabular}{cccc|c|}
\hline 08:00:00 & $\begin{array}{c}110 \\
\text { Pasar Minggu - Lenteng Agung }\end{array}$ & \\
\hline 08:00:00 & $\begin{array}{c}\text { 08:00:55 } \\
\text { Lenteng Agung }- \text { Pasar Rebo }\end{array}$
\end{tabular}

Gambar 14. Siklus pagi hasil pengamatan
Tabel 5. Waktu persinyalan sore (sibuk sore)

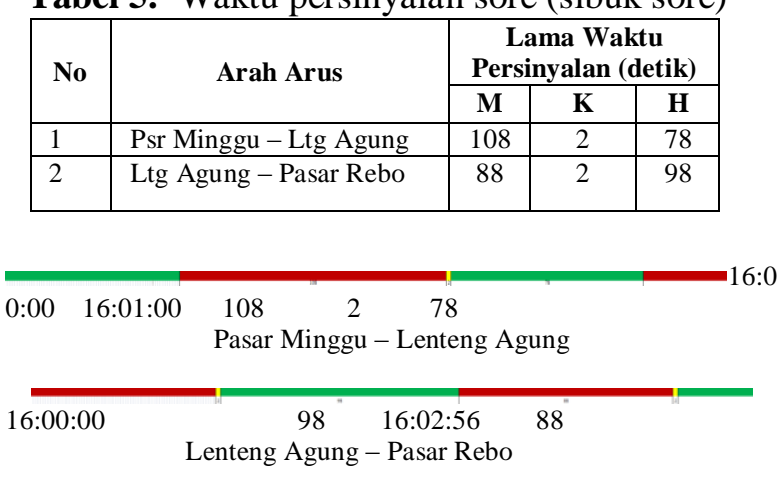

Gambar 15. Siklus sore hasil pengamatan

Dari hasil pengamatan dilapangan terlihat waktu siklus pagi di persimpang untuk arah Pasar Minggu - Lenteng Agung dan Lenteng Agung adalah 202 detik. Dan waktu siklus sore di persimpang untuk arah Pasar Minggu - Lenteng Agung dan Lenteng Agung Pasar Rebo adalah 188 detik. Waktu persinyalan tersebut yang akan digunakan untuk menganalisa.

\section{PEMBAHASAN}

Dalam mengevaluasi kinerja simpang bersinyal dalam kondisi ideal adalah dengan tidak mempertimbangkan KRL yang melintas dipersimpangan. Jumlah arus lalu lintas yang digunakan dalam menganalisa dengan menggunakan metode MKJI adalah Jumlah kendaraan (Volume) per jam pada jam sibuk pagi dan sore, yang merupakan hasil reduksi data survei di lapangan dengan pengklasifikasian berdasarkan jenis kendaraan serta arah arus lalu lintas. Sedangkan waktu terpadat yang digunakan dalam menganalisa adalah jam tersibuk pagi dan sore dengan arus lalu lintas arah Lenteng Agung menuju Pasar Minggu dan arus lalu lintas arah Pasar Minggu menuju Lenteng Agung. Jumlah kendaraan (volume) pada jam sibuk pagi dan sore tersebut seperti pada Gambar. 16 dan Gambar.17. 


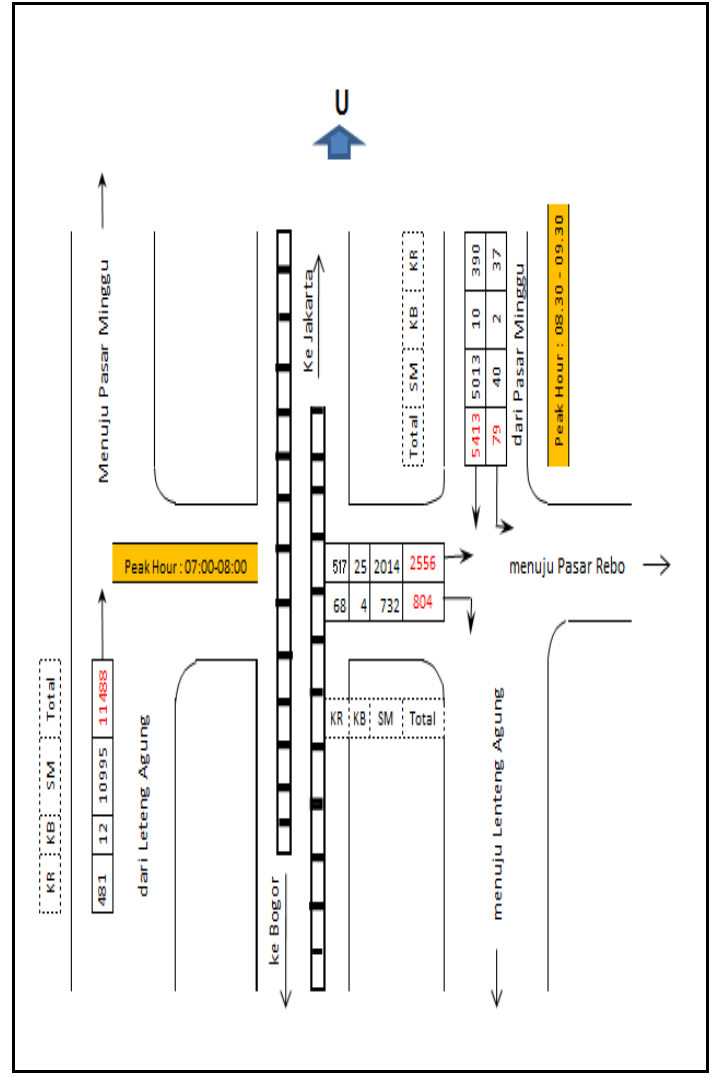

Gambar 16. Volume jam sibuk pagi

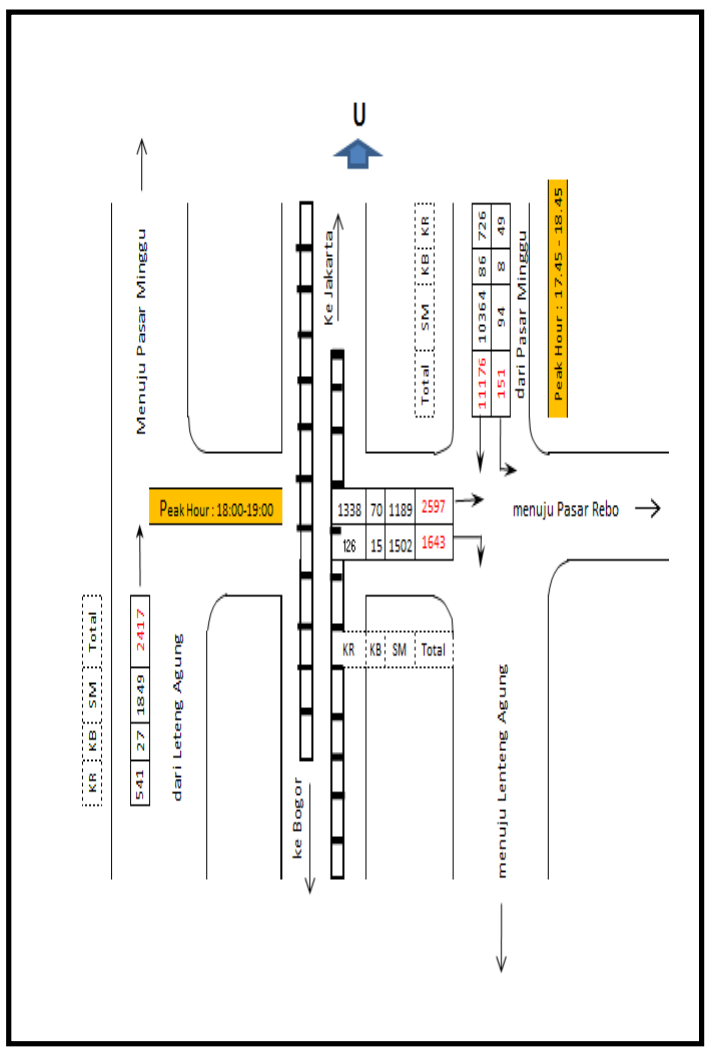

Gambar 17. Volume jam sibuk sore
Untuk mengevaluasi kinerja simpang bersinyal dalam kondisi ideal dilakukan dengan 3 (tiga tahap), antara lain :

1. Evaluasi kinerja simpang sesuai dengan pengaturan lampu lalu lintas sebenarnya (eksisting).

2. Evaluasi kinerja simpang dengan pengaturan lampu lalu lintas hasil dari perencanaan.

3. Evaluasi kinerja simpang sesuai dengan pengaturan lampu lalu lintas sebenarnya (eksisting) vs pengaturan lampu lalu lintas hasil dari perencanaan.

\section{Evaluasi Kinerja Simpang Sesuai Dengan Pengaturan Lampu Lalu Lintas Sebenarnya (eksisting).}

Sebelum menganalisa kinerja simpang, penulis mendistribusikan arus lalu lintas kepada berbagai pendekat melalui pengalokasian waktu hijau pada masingmasing pendekat. Pendekat adalah daerah dari suatu lengan persimpangan jalan untuk kendaraan mengantri sebelum keluar melewati garis henti. Untuk masing arah arus lalu lintas, kode pendekat digunakan adalah Utara (U) dan Barat (B) seperti pada Tabel 6 dibawah ini

Tabel 6. Kode Pendekat

\begin{tabular}{|l|l|c|}
\hline No & Arah Arus & $\begin{array}{c}\text { Kode } \\
\text { Pendekat }\end{array}$ \\
\hline 1 & Pasar Minggu - Lenteng Agung & U (utara) \\
\hline 2 & Lenteng Agung - Pasar Rebo & B (barat) \\
\hline
\end{tabular}

Dari hasil pengamatan waktu persinyalan langsung dilapangan dan arus lalu lintas telah diolah, kemudian dianalisa dengan memasukan kedalam rumus-rumus MKJI sehingga didapat parameter kinerja simpang yang akan ditinjau adalah jumlah kendaraan antri, panjang antrian, tundaan dan tingkat pelayanan simpang.

Kinerja simpang sesuai dengan pengaturan lampu lalu lintas sebenarnya 
(eksisting) pagi, waktu siklus sebesar 202 detik untuk kedua pendekat ( Utara maupun Barat). Waktu nyala hijau untuk pendekat Utara sebesar 110 detik, Sedangkan untuk pendekat Barat, waktu nyala hijau 80 detik. Tundaan rata-rata kendaraan pendekat Utara dan barat adalah 35,82 detik/smp dan 56,88 detik/smp. Tingkat pelayanan simpang pada pendekat Utara adalah D dan tingkat pelayanan simpang pada pendekat Barat adalah E. Ini artinya kondisi kinerja simpang pendekat Barat lebih buruk daripada pendekat Utara. Hasil analisa dapat dilihat pada Tabel 8.

Begitu juga dengan pengaturan lampu lalu lintas sebenarnya (eksisting) sore. Waktu siklus sebesar 188 detik untuk pendekat Utara (arah Pasar Minggu menuju Lenteng Agung) dengan waktu nyala hijau sebesar 78 detik. Sedangkan untuk pendekat Barat (arah Lenteng Agung menuju Pasar Rebo) waktu siklusnya sebesar 188 detik dengan waktu nyala hijau 98 detik, maka tundaan rata-rata kendaraan pendekat Utara dan barat adalah 1507,99 detik/smp dan 58,98 deik/smp. Tingkat pelayanan simpang pada pendekat Utara adalah $\mathrm{F}$ dan tingkat pelayanan simpang pada pendekat Barat adalah E. Ini artinya kondisi kinerja simpang pendekat Utara lebih buruk daripada pendekat Barat. Hasil analisa dapat dilihat pada Tabel 9.

\section{Evaluasi Kinerja Simpang Dengan Pengaturan Lampu Lalu Lintas Hasil Dari Perencanaan.}

Berdasarkan data geometrik, pengaturan lalu lintas, kondisi lapangan dan jumlah kendaraan (volume) per jam pada jam sibuk (peak hour) yang telah diolah, kemudian dianalisa dengan menggunakan metode Manual Kapasitas Jalan Indonesia . Dari hasil analisa perencanaan tersebut didapat karakteristik sinyal lalu lintas, waktu hijau (g) dan waktu siklus (c). Selain itu didapat kapasitas persimpangan (C), derajat kejenuhan (DS), panjang antrian (NQ), jumlah kendaraan terhenti (NS), tundaan (Delay) dan tingkat pelayanan, sehingga diketahui kinerja simpang.

Kinerja simpang sesuai dengan pengaturan lampu lalu lintas hasil perencanaan pagi, didapat waktu siklus sebesar 63 detik baik pendekat Utara (arah Pasar Minggu menuju Lenteng Agung) maupun pendekat Barat (arah Lenteng Agung menuju Pasar Rebo). Waktu nyala hijau pendekat Utara adalah 29 detik dan pendekat barat 23 detik. Tundaan rata-rata kendaraan pendekat Utara dan barat adalah 20,51 detik/smp dan 25,24 detik/smp. Tingkat pelayanan simpang pada pendekat Utara adalah C, sedangakan tingkat pelayanan simpang pada pendekat Barat adalah D. Ini artinya kondisi kinerja simpang pendekat Barat lebih buruk daripada pendekat Utara. Hasil analisa dapat dilihat pada Tabel 10. 


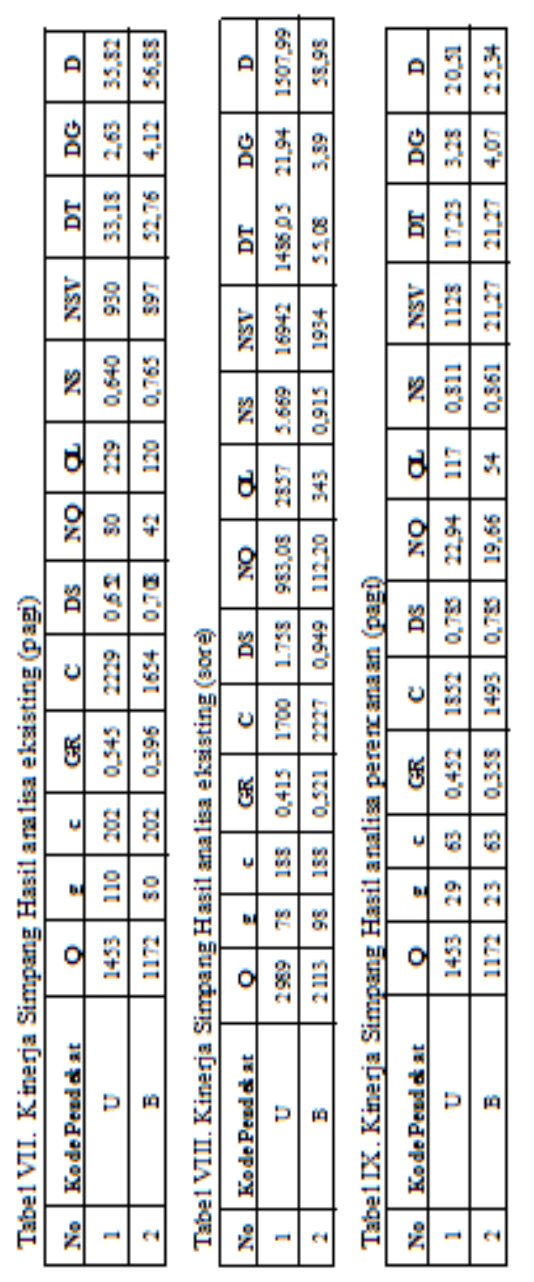

3. Evaluasi Kinerja Simpang Sesuai Dengan Pengaturan Lalu Lintas Sebenarnya (eksisting) vs Pengaturan Lampu lalu Lintas Hasil Dari Perencanaan.

Hasil analisa simpang bersinyal dengan pengaturan lampu lalu lintas sebenarnya (eksisting $=\mathrm{e})$ vs pengaturan hasil perencanaan $(\mathrm{p})$, antar lain sebagai berikut :

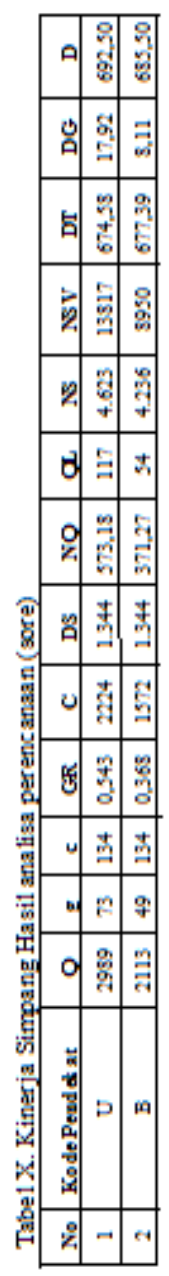

a. $\mathrm{g}_{\mathrm{a}}>\mathrm{g}_{\mathrm{p}}, \mathrm{c}_{\mathrm{a}}>\mathrm{c}_{\mathrm{m}}, \mathrm{GR}_{\mathrm{m}}>\mathrm{GR}_{\mathrm{p}}$, maka $\mathrm{C}_{\mathrm{e}}>\mathrm{C}_{\mathrm{p}}$ dan $\mathrm{DS}_{\mathrm{e}}<\mathrm{DS}_{\mathrm{p}}$

b. $\mathrm{GR}_{\mathbb{a}}>\mathrm{GR}_{\mathrm{p}}, \mathrm{C}_{\mathrm{a}}>\mathrm{C}_{\mathrm{p}}$, maka $\mathrm{NQ}_{\mathbb{a}}$ $>\mathrm{NQ}_{\mathrm{p}}$ dan $\mathrm{QL}_{\mathrm{e}}>\mathrm{QL}_{\mathrm{p}}$

c. $\mathrm{DS}_{\mathbb{a}}<\mathrm{DS}_{\mathrm{p}}$, maka $\mathrm{NS}_{\mathbb{a}}<\mathrm{NS}_{\mathrm{p}}$ dan $\mathrm{Nsv}_{\mathrm{e}}<\mathrm{Nsv}_{\mathrm{p}}$

d. $\mathrm{NQ}_{\mathbb{e}}>\mathrm{NQ}_{\mathrm{p}}$, maka $\mathrm{D}_{\mathrm{e}}>\mathrm{D}_{\mathrm{p}}$

2. Pendekat Barat (pagi)

a. $g_{a}>g_{p}, c_{a}>c_{a}, G_{a}>G_{p}$, maka $\mathrm{C}_{\mathrm{e}}>\mathrm{C}_{\mathrm{p}}$ dan $\mathrm{DS}_{\mathrm{e}}<\mathrm{DS}_{\mathrm{p}}$

b. $\mathrm{GR}_{\mathrm{a}}>\mathrm{GR}_{\mathrm{p}}, \mathrm{C}_{\mathrm{u}}>\mathrm{C}_{\mathrm{p}}$, maka $\mathrm{NQ}_{\text {a }}$ $>\mathrm{NQ}_{\mathrm{p}}$ tetapi $\mathrm{QL}_{\mathrm{e}}>\mathrm{QL}_{\mathrm{p}}$

1. Pendekat Utara (pagi) 
c. $\mathrm{DS}_{\mathrm{a}}<\mathrm{DS}_{\mathrm{p}}$, maka $\mathrm{NS}_{\mathbb{q}}<\mathrm{NS}_{\mathrm{p}}$ dan $\mathrm{Nsv}_{a}<\mathrm{Nsv}_{\mathrm{p}}$

d. $\quad \mathrm{NQ}_{\mathbb{\sharp}}>\mathrm{NQ}_{\mathrm{p}}$, maka $\mathrm{D}_{\mathbb{e}}>\mathrm{D}_{\mathrm{p}}$

3. Pendekat Utara (sore)
a. $\mathrm{g}_{\mathbb{a}}>\mathrm{g}_{\mathrm{p}}, \mathrm{c}_{\mathrm{a}}>\mathrm{c}_{\mathbb{m}}, \mathrm{GR}_{\mathbb{m}}<\mathrm{GR}_{\mathrm{p}}$, tetapi $\mathrm{C}_{\mathrm{e}}<\mathrm{C}_{\mathrm{p}}$ maka $\mathrm{DS}_{\mathrm{a}}>\mathrm{DS}_{\mathrm{p}}$
b. $\mathrm{GR}_{\mathrm{e}}<\mathrm{GR}_{\mathrm{p}}, \mathrm{C}_{\mathrm{e}}<\mathrm{C}_{\mathrm{p}}$, tetapi $\mathrm{NQ}_{\mathrm{e}}$ $>\mathrm{NQ}_{\mathrm{p}}$ dan $\mathrm{QL}_{\mathrm{e}}>\mathrm{QL}_{\mathrm{p}}$
c. $\mathrm{DS}_{\mathrm{q}}>\mathrm{DS}_{\mathrm{p}}$, maka $\mathrm{NS}_{\mathrm{q}}>\mathrm{NS}_{\mathrm{p}}$ dan $\mathrm{Nsv}_{\mathrm{e}}>\mathrm{Nsv}_{\mathrm{p}}$
d. $\mathrm{NQ}_{\mathbb{a}}>\mathrm{NQ}_{\mathrm{p}}$, maka $\mathrm{D}_{\mathrm{a}}>\mathrm{D}_{\mathrm{p}}$

4. Pendekat Barat (sore)
a. $g_{a}>g_{p}, c_{m}>c_{m}, G R_{\mathbb{a}}>G_{p}$, maka $\mathrm{C}_{\mathrm{e}}>\mathrm{C}_{\mathrm{p}}$ dan $\mathrm{DS}_{\mathrm{e}}<\mathrm{DS}_{\mathrm{p}}$
b. $\mathrm{GR}_{\mathrm{e}}>\mathrm{GR}_{\mathrm{p}}, \mathrm{C}_{\mathrm{e}}>\mathrm{C}_{\mathrm{p}}$, tetapi $\mathrm{NQ}_{\mathrm{m}}$
$<\mathrm{NQ}_{\mathrm{p}}$ dan $\mathrm{QL}_{\mathrm{e}}>\mathrm{QL}_{\mathrm{p}}$
c. $\mathrm{DS}_{\mathrm{e}}<\mathrm{DS}_{\mathrm{p}}$, maka $\mathrm{NS}_{a}<\mathrm{NS}_{\mathrm{p}}$ dan $\mathrm{Nsv}_{\mathrm{e}}<\mathrm{Nsv}_{\mathrm{p}}$
d. $\mathrm{NQ}_{\mathbb{e}}<\mathrm{NQ}_{\mathrm{p}}$, maka $\mathrm{D}_{\mathrm{e}}<\mathrm{D}_{\mathrm{p}}$

Hasil analisa tersebut diatas dapat dilihat pada Tabel 12 dan Tabel 13
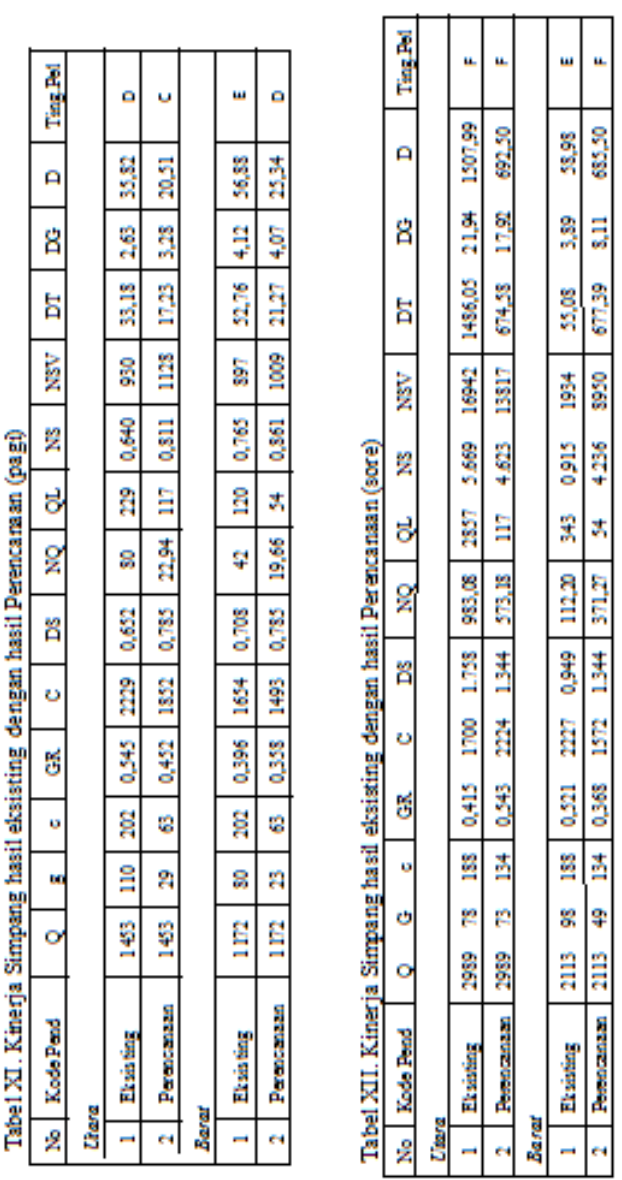

Evaluasi kinerja simpang berdasarkan MKJI 1997 baik dengan pengaturan lampu lalu lintas sebenarnya (eksisting) dan pengaturan hasil perencanaan, menunjukkan bahwa :

1. Pendekat Utara pagi dan Barat pagi, kondisi eksisting lebih buruk dari kondisi perencanaan, ini telihat dari besar tundaannya serta tingkat pelayanannya. Besar derajat kejenuhan keduanya $<1$.

2. Pendekat Utara sore, kondisi perencanaan dan kondisi eksisting sama-sama buruk, ini telihat dari besar tundaannya serta tingkat pelayanannya. Besar derajat kejenuhan keduanya $>1$

3. Pendekat Utara pagi, kondisi eksisting lebih baik dari kondisi perencanaan, ini telihat dari besar tundaannya. Besar derajat kejenuhan kondisi eksisting < 1 sedangkan derajat kejenuhan kondisi perencanaan $>1$.

4. Tidak selalu waktu hijau (g) besar, waktu siklus (c) besar maka kapasitas (C) akan besar, begitu sebaliknya , tetapi rasio hijau (g/c) yang menentukan besarnya kapasitas (C) 
maupun derajat kejenuhan (DS atau $\mathrm{Q} / \mathrm{C})$. Semakin besar rasio hijau (g/c), semakin besar kapasitas simpang, semakin kecil derajat kejenuhannya.

5. Nilai Derajat kejenuhan (DS) besar maka angka henti (Ns) besar dan jumlah kendaraan terhenti (Nsv) juga besar, begitu sebaliknya.

6. Jumlah kendaraan antri (NQ) besar, maka Tundaan D (tundaan) besar, dan sebaliknya.

\section{SIMPULAN}

1. Pada saat jam sibuk pagi dan sore hari, kondisi arus lalu lintas dari Pasar Minggu menuju Lenteng Agung pada pengamatan pagi (perencanaan) adalah lebih baik dari Lenteng Agung menuju Pasar Rebo. Kondisi ini terlihat dari DS $<1$, dan tundaan lalu lintas rata-rata rendah, sehingga tingkat pelayanan simpang lebih baik.

2. Dengan tidak mempertimbangkan adanya KRL yang lewat, kemacetan terjadi karena padatnya arus lalu lintas dan sebagai akibat tundaan (delay). Tundaan tersebut akibat interaksi antara kendaraan satu dengan kendaraan lainnya (lalu lintas) dan percepatan atau perlambatan akibat membelok dan berhenti (geometrik).

3. Tundaan terbesar adalah tundaan lalu lintas, karena dipengaruhi oleh waktu siklus, jumlah kendaraan antri dan kapasitas simpang

4. Dengan waktu siklus yang ada, baik dari hasil pengamatan langsung dilapangan (eksisting) maupun hasil perencanaan, kemacetan tetap terjadi pada arus lalu lintas arah Tanjung Barat - Pasar Rebo karena kemacetan tersebut bukan hanya konflik dengan lalu lintas dari Pasar Minggu menuju Lenteng Agung tetapi juga akibat KRLyang melintas.

\section{SARAN}

1. Untuk menghindari kemacetan arus lalu lintas dari kedua arus lalu lintas,maka waktu siklus eksisting disesuaikan dengan waktu siklus hasil perencanaan

2. Diperlukan pengaturan sinyal secara manual, sehingga dapat disesuaikan dengan waktu kedatangan KRL.
3. Kemacetan yang terjadi pada simpang bersinyal Tanjung Barat - Pasar Minggu tersebut juga akibat KRL yang melintas. maka sebaiknya dilakukan penelitian lebih lanjut tentang pengaturan simpang bersinyal dengan waktu kedatangan KRL.

\section{DAFTAR PUSTAKA}

Departemen Pekerjaan Umum (1997) : Simpang Bersinyal, Manual kapasitas Jalan Indonesia, 2, 6-70

Departemen Pendidikan dan Kebudayaan Direktorat Jendral Pendidikan Tinggi (1998) : Simpang, Buku Ajar Rekayasa Lalu Lintas, 1-2

Munawar, Ahmad (2009) : Manajemen Lalu Lintas Perkotaan, Jogjakarta, 43-49

Putranto, Leksmono Suryo (2009) : Rekayasa Lalu Lintas, Indeks, 9

Sri Hendarto. Al Rasyid, Harun. dan RudiHermawan (2009) : Arus Lalu Lintas Kereta. Catatan Kuliah DasarDasar Transportasi, Teknik Sipil Dan Lingkungan, Institut Teknologi Bandung, 27-28 Susanto, Benidiktus. dan Santoso, Yohanes Jarot (2010) : Efektivitas Countdown Timer pada Simpang BerApill, Prosiding Konteks 4, I-359.

Wikrama, A.A Ngurah Jaya. Dan Mataram, I Nyoman Karnata. (2010) : Evaluasi Kinerja Simpang Patungan Ngurah Rai (Simpang Jalan I Gusti Ngurah Rai Jalan Airport Ngurah 